\title{
First record of Chaetacanthus magnificus (Polychaeta: Polynoidae) from the northeast coast of Brazil, with an overview of its taxonomic history
}

\author{
Rafael Justino de Brito', José Eriberto De Assis² and Martin Lindsey Christoffersen ${ }^{2}$ \\ 1. Laboratório e Coleção de Invertebrados Paulo Young, Departamento de Sistemática e Ecologia, Centro de Ciências Exatas e da Natureza, Uni- \\ versidade Federal da Paraíba, Brasil. \\ 2. Laboratório de Filogenia, Departamento de Sistemática e Ecologia, Centro de Ciências Exatas e da Natureza, Universidade Federal da Paraíba, \\ Brasil; eri.assis@gmail.com
}

Received 19-VI-2012 Corrected 6-IX-2012 Accepted 29-X-2012

\begin{abstract}
Polynoidae is a diverse group of polychaetes known as scale-worms, found in different marine regions. However this rich family is little studied in Brazil, especially along the northeastern coast of the country. We report Chaetacanthus magnificus, a first record for the northeastern coast of Brazil, establish this species as valid, differentiating it from other synonyms found in several studies which report polychaetes in Central and South America. The polychaetes found by Project Algae of Paraíba are in the collection of Laboratory of Marine Invertebrates Paulo Young, Universidade Federal da Paraíba, Brazil.
\end{abstract}

KEY WORDS

Polychaetes, Polynoidae, scale-worm, South America, new record.

\section{RESUMEN}

Polynoidae es un grupo diverso de poliquetos conocidos como gusanosescamosos, que se encuentra en diferentes regiones marinas. Sin embargo, esta diversa familia es poco estudiada en Brasil, especialmente a lo largo de la costa noreste del país. Reportamos Chaetacanthus magnificus, primer registro para la costa noreste de Brasil, establecida esta especie como válida, diferenciándola de otros sinónimos encontrados en varios estudios que reportan poliquetos en América Central y del Sur. Los poliquetos encontrados por el Proyecto Algas de Paraíba están en la colección del Laboratorio de Invertebrados Marinos Paulo Young, Universidad Federal da Paraíba, Brasil.

\section{PALABRAS CLAVE}

Polychaetes, Polynoidae, gusanos escamosos, América del Sur.
The polynoids constitute a peculiar group of scaleworms inhabiting marine habitats from intertidal zones to the deep-sea (Ruff, 1995), from warm waters such as the tropical seas of northeastern Brazil (Nonato \& Luna, 1970) to cold waters as in Alaska (Hartman, 1948), and can withstand hydrothermal vents (Pettibone, 1983; 1984; 1989). These worms are widely distributed along the entire marine realm, where they find food and shelter for their survival. This group was recorded for the Brazilian coast in the works of Morgado and Amaral (1981), Amaral and Nonato (1982), and Amaral et al. (2012), totaling approximately 151 records.

Among the records of that diverse family from Brazil, the species Chaetacanthus magnificus Grube, 1876 was the first record of the genus for the South Atlantic in the work of Nonato (1981), where one specimen was collected in the tidal zone in Ubatuba, São Paulo. This species was recorded later from the Brazilian coast by Amaral and Nonato (1982) and Amaral et al. (2012). Herein, it is the target for the first report from the northeast coast of Brazil, where efforts to identify the fauna of polychaetes are still scarce.

Other occurrences of this species are from Central and South America: Mexico-Pacific coast, Panama-Atlantic coast, Ecuador, Colombia, and Brazil (Treadwell, 1914; Monro, 1928; Hartman, 1938; 1939; Allen, 1957; Perkins \& Savage, 1975; Fauchald, 1977; Laverde-Castillo, 1986; Salazar-Vallejo, 1990; 1996; Salazar-Vallejo et al., 2004; Salazar-Silva, 2006; Hernández-Alcántara et al., 2008). As well as recording the species, we discuss the synonymy of C. magnificus, discuss characters that distinguish this species from the remaining species of the genus, and remark 
on the necessity of revising some of the type specimens in Chaetacanthus.

\section{Taxonomic History}

Seidler (1922) transferred Iphione magnifica Grube, 1875 to Chaetacanthus magnificus (Grube, 1876). The establishment of the new genus Chaetacanthus Seidler, 1923 was justified by the presence of branchiae on the dorsal part of the parapodia, located especially on the elytra and cirrophores, and structures of chitin present in center of the elytrae, characters that did not occur in the closest genera such as Iphione (Kinberg, 1856) and Lepidonotus (Leach, 1816). Besides, the notochaetae are different from the notochaetae found in the genus Lepidonotus. Seidler also emphasized the differences between Chaetacanthus and Euphione, clarifying some existing doubts about the validity of these two genera. He further indicated that Lepidonotus (Physalidonotus) barbatus (Augener, 1910) is not a synonym of $C$. magnificus.

Nowadays, three more species are known besides the type species of Chaetacanthus: C. pilosus (Treadwell, 1937), C. barbatus (Augener, 1910) and C. pomareae (Kinberg, 1856).

Some records lead us to doubt the validity of a few type specimens in the genus. Seidler (1923) questioned some identifications. He reports that Augener (1910) described a specimen with $35 \mathrm{~mm}$ in length, with characters of $C$. magnificus, but argued that this specimen was too big to belong to this species, commenting that size interferes with body rigidity. Hartman (1939) also refers to a questionable identification of a single specimen from the North Pacific in the same work by Augener. Thus, the synonymization of Lepidonotus (Physalidonotus) barbatus with $C$. barbatus by Augener may also be questioned under these circumstances.

Another suggested synonym of $C$. magnificus is Polynoe branchiata Treadwell (1901). Curiously, the identification card of $P$. branchiata in the Smithsonian Institution (IZ WRM 16008, card-USNM 16008), identified by Treadwell, bears comments by Dr. Marian H. Pettibone that the specimen may belong to C. magnificus.

Hartman (1938) reports another synonym for Chaetacanthus magnificus. She informs us that Treadwell considered Lepidonotus pilosus from the south of the Gulf of California a synonym of $C$. pilosus, because the specimen has branchiae on the elytrophores, a heavy ornamentation of the scales, and chaetae typical of $C$. magnificus.

Hernández-Alcántara et al. (2008) also report Lepidonotus pilosus as a synonym of Chaetacanthus magnificus. However, Salazar-Silva (2006) reiterated that C. pilosus was synonymized with C. magnificus by Hartman (1939) (Holotype ZMB 1059), but after a comparison between C. pilosus and the holotype of L. pilosus (AMNH 3531), she remarked that there are sufficient differences among the two species to justify their validity. In the same work Salazar-Silva puts Lepidonotus panamensis Hartman, 1939 (cited as Lepidonotus pomareae panamensis Hartman, 1939 but raised to species rank by Hartman (1948)) into the synonymy of $C$. pilosus, stating that both species have the same characters.

This affirmation of Salazar-Silva makes a revision of the type specimens of species of Chaetacanthus necessary, because L. panamensis (Hartman, 1939) is also a synonym of C. pomareae and Salazar-Vallejo (1990) illustrates differences in the parapodia between L. panamensis and C. magnificus, which support the suggestion that there remain important differences between the genera Lepidonotus and Chaetacanthus.

Another genus that approaches Chaetacanthus is Euphionella Monro, 1936, which has saccular branchiae among its parapodia, as well as coriaceous and well ornamented elytrae (Amaral \& Nonato, 1982). However, Euphionella has dorsal expansions on the chaetigers without scales, but may have an ornamentation known as "pseudo-elytrae" (Rozbaczylo et al., 2005:76. Figs. 3-I).

On the basis of the above comments, we believe that the synonyms established previously for $C$. magnificus were based on the similarities of the lepidonotinoid prostomium in Chaetacanthus, Euphione, Iphione and Lepidonotus, as well as on similarities of their chaetae and in the ornamentation of their elytrae. The taxonomic confusions among these genera remains due to the absence of taxonomic revisions within the family Polynoidae, particularly for the genus Lepidonotus. Notwithstanding, the works of Salazar-Silva (2006) and Amaral and Nonato (1982) support with taxonomic discussions and illustrations that the differences among C. magnificus and the remaining genera are valid. Even though they all show a lepidonotinoid prostomium, Chaetacanthus may be clearly distinguished by the presence of digitiform branchiae among the parapodia and by the disposition of the chitinous plates in the center of the elytrae in C. magnificus.

\section{METHODOLOGY}

Specimens were collected from various locations on the coast of Paraiba (S Atlantic, Brazil), during the Algae Project of Paraiba (1981-1982). The dredged material was collected at stations 63, 69, 84 and 87 (Fig. 1). After sorting, the animals were preserved in alcohol $70 \%$, and 
observed under stereomicroscopes, while parapodia and scales were examined under a compound microscope. All drawings were done with a camera lucida mounted to the stereomicroscope.

Photos were taken with a camera mounted on the stereomicroscope (Leica M205c; camera DFC295). Taxonomic keys were used from the available literature for the identification of species. The nomenclature of the segments and appendages follow the terms in the descriptions of Tebble and Chambers (1982), Hanley and Burke (1991), Ruff (1995), and Imajima (1997). All the specimens are deposited in Coleção de Invertebrados Paulo Young, Universidade Federal da Paraíba, Brazil, under the acronym (POLY-UFPB).

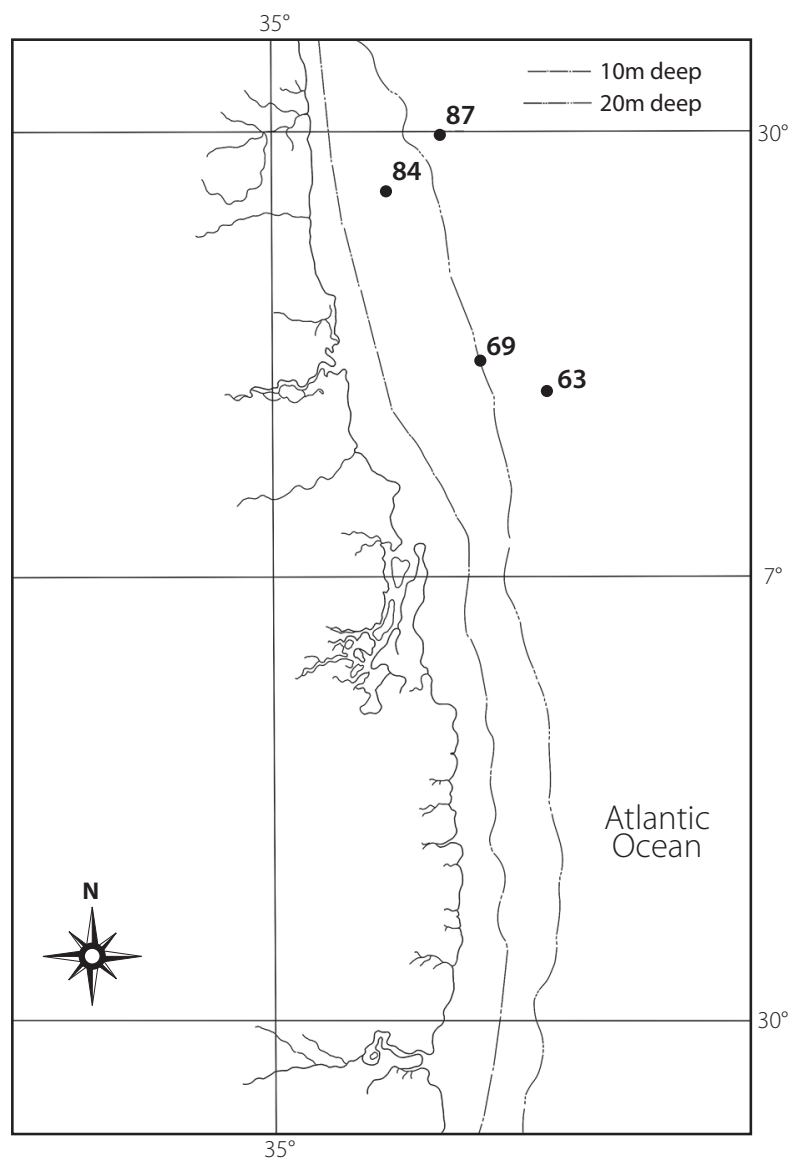

FIG. 1. Map of the coast of the State of Paraíba - Brazil, showing four localities where C. magnificus was collected (St. 63, 69, 84, 87).

\section{Systematics}

Family Polynoidae Kinberg, 1856

Subfamily Lepidonotinae Willey, 1902

Genus Chaetacanthus Seidler, 1923

Chaetacanthus magnificus Grube, 1876

Iphione magnifica Grube, 1876: 51

Polynoe branchiata Treadwell, 1901: 186, Figs. 5-7.

Lepidonotus (Physalidonotus) barbatus Augener, 1910: 244-246, Figs. 4-6.

Lepidonotus pilosus Treadwell, 1937: 141-143, Figs. 1-7

Lepidonotus panamensis Hartman, 1939: 44-46, PI. 6, Figs. 70-77. (as L. pomareae panamensis)

\section{Main references}

Seidler, 1924: 97-98, Fig. 14, Monro, 1928: 558, Hartman, 1939: 28; 1948) (Trinidad; type-species).

\section{Diagnosis}

Body stout, with 25 chaetigerous segments. Digitiform branchiae among the parapodia. Elytra with polygonal or spherical chitinous structures.

\section{Material examined}

POLY-UFPB 05, 09 and 799, 6050' $\mathrm{S}^{\prime}$; 344ㅇ' $\mathrm{W}$, in 30m; St. 63; POLY-UFPB 98, 6²9'S; 34048'W; St. 87; POLY-UFPB 03, 97, 99, 101 and $102,6^{\circ} 46^{\prime} \mathrm{S} ; 34^{\circ} 47^{\prime} \mathrm{W}$, in $18 \mathrm{~m}$; St. 69. POLYUFPB 04, 6³3'S; 345' $\mathrm{W}$, in 14m; St. 84.

\section{Description}

Body robust, elliptical in cross section, with $4,7 \mathrm{~cm}$ in length, including palps and pygidial cirri. Width $1,2 \mathrm{~cm}$, including chaetae; 25 chaetigers. Prostomium bilobed, with two pairs of eyes; anterior pair dorsolateral, near widest portion of prostomium, posterior pair near basis of prostomium, converging towards the midline, close to the nuchal fold (Fig. 2). Median antenna slightly longer than lateral antennae, both having a subdistal inflation, culminating abruptly in a sharp point; cylindrical ceratophores, median antenna with ceratophores larger than lateral antennae, antennae and tentacular cirri with two dark brown rings close to inflation. A pair of large palps, slightly longer than median antenna, culminating in a fine point, with eight transverse rows of papillae, from its base to the apex.

Tentacular segment with two pairs of cylindrical tentaculophores, with three chaetae on the anterodorsal bases. Buccal cirri larger than following ventral cirri, pharynx with nine pairs of papillae and two pairs of maxillary jaws.

Parapodia biramous, glabrous and strong, with dorsal cirrus of same shape as the middle antenna. Notopodia 


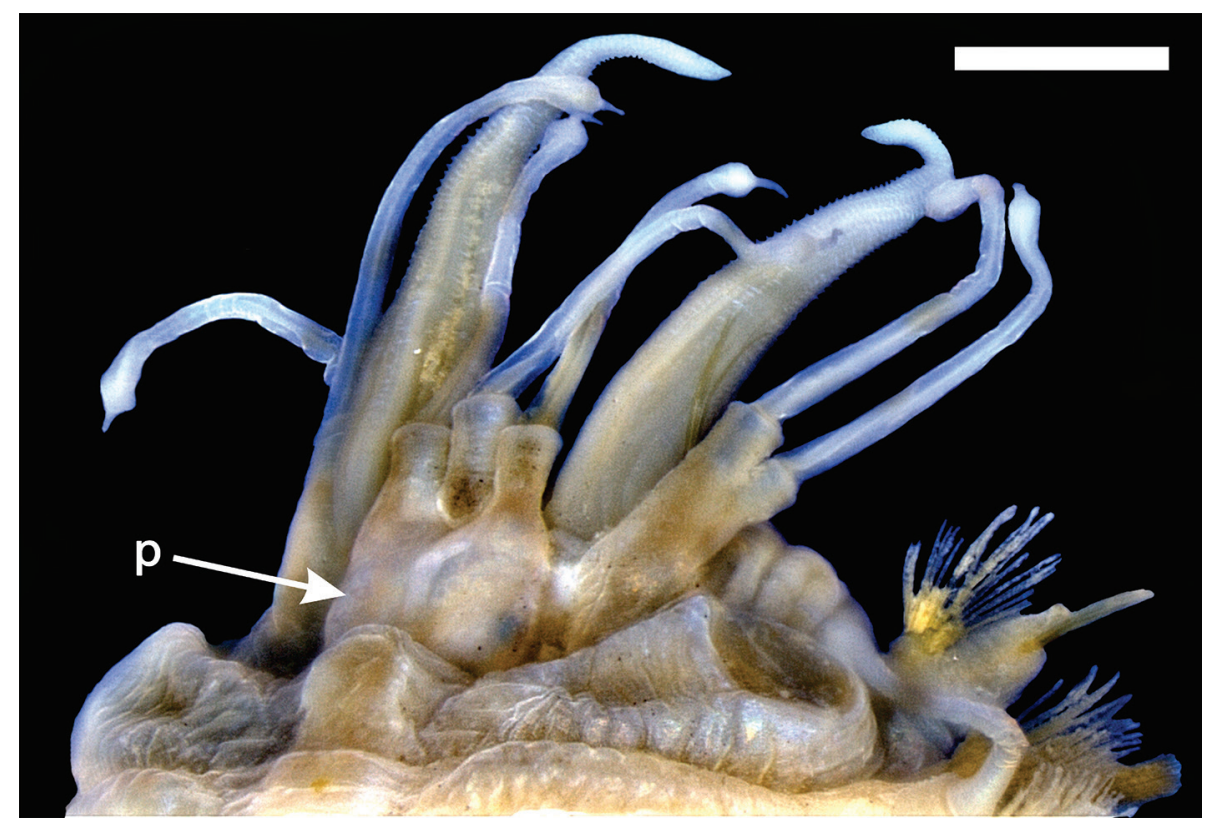

FIG. 2. Anterior end of $C$. magnificus, showing the bilobed prostomium, with two pairs of eyes, antennae and palps ( $\mathrm{p}=$ prostomium). Scale bar: $(1 \mathrm{~mm})$.

Color version of this photograph and the following, available at: http://investiga.uned.ac.cr/revistas/index.php/cuadernos/index.

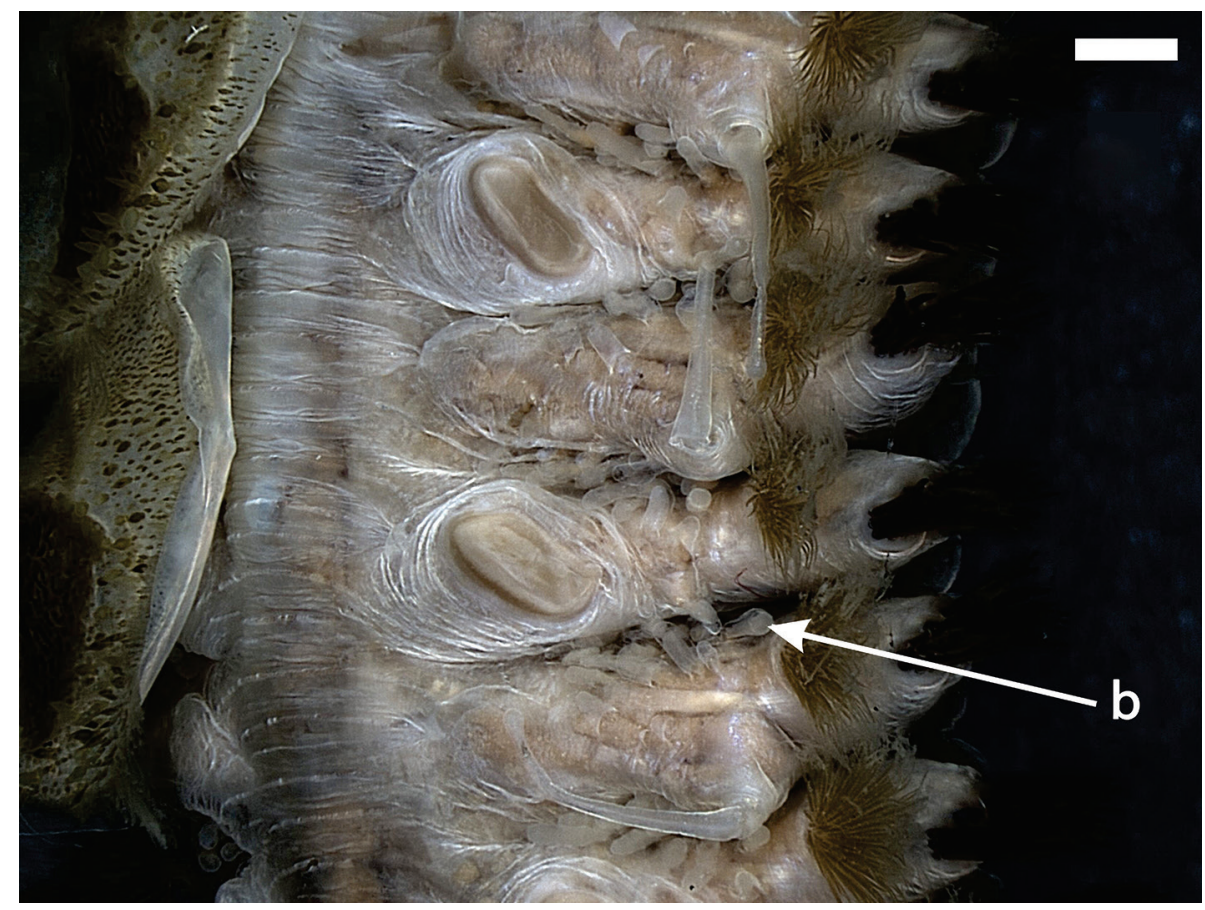

FIG. 3. Parapodia of C. magnificus, showing the saccular branchiae of digitiform aspect on median chaetigerous segments $(b=$ branchiae). Scale bar: $(1 \mathrm{~mm})$. 
short, on anterior face of neuropodium, notochaetae with spinous rows of fine serrations along convex edge. Neuropodia big, neurochaetae more numerous than notochaetae, with teeth in subdistal inflation. Branchiae among parapodia with digitiform aspect (Fig. 3), located near to elytrophores.

12 pairs of elytrae, broad, leathery, in the center of which there are refractive polygonal or spherical chitinous structures (Fig. 4). Elytrae with papillae in the margin. Surface conspicuously ornamented, with micro and macrotubercles. There is a group of papillae in internal side of margin (close to midline of body (Figs. 5-6)).

Nephridial papillae cylindrical, starting from chaetiger six. Ventral cirri conical, ending in fine tips. Two pairs of anal cirri, identical to median antenna in shape and ventral pigmentation.

\section{Habitat}

In all reports reviewed, Chaetacanthus magnificus was found on the continental shelf between 5 and $197 \mathrm{~m}$ deep. On the coast of Paraíba, specimens were collected from 12-30m, on rocks and soft bottoms. At Praia do Francês, State of Alagoas, Brazil they occurred in corals and among stones.

\section{Distribution}

Amphiamerican: Great Caribbean, East Pacific and Brazil (South Coast) (Fauchald, 1977; Amaral \& Nonato, 1982).

\section{Remarks}

The specimens examined vary in size, from 2 to $5 \mathrm{~cm}$. The description and drawings in the work of Amaral and Nonato (1982) are identical to those of specimens of this new report. We further report a group of papillae in the internal margin of the elytrae, which were illustrated but not described by those authors. This character should be used for comparison within the genus Chaetacanthus.

\section{ACKNOWLEDGEMENTS}

We heartily thank Ana Carolina Toscano de Souza for photographs and Sílvio Felipe who helped us in the edition of images. We also thank the referees for valuable suggestions on the manuscript. CAPES provided a doctorate scholarship to J. E. De Assis and CNPq a productivity grant to Dr. M. L. Christoffersen.

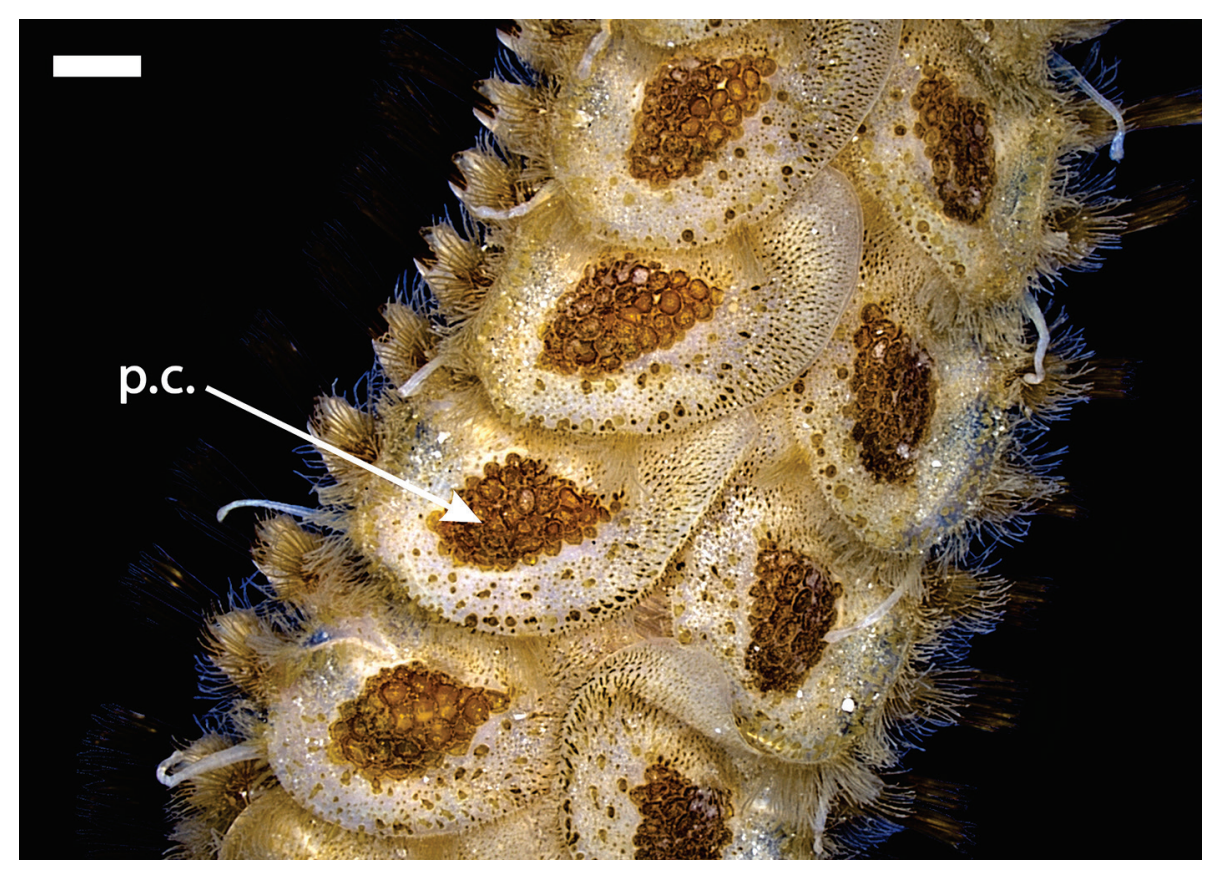

FIG. 4. Elytra of $C$. magnificus from median chaetigers, showing in the center the polygonal structures or plates of chitin (p.c. = plate of chitin), Scale bar: $(1 \mathrm{~mm})$. 


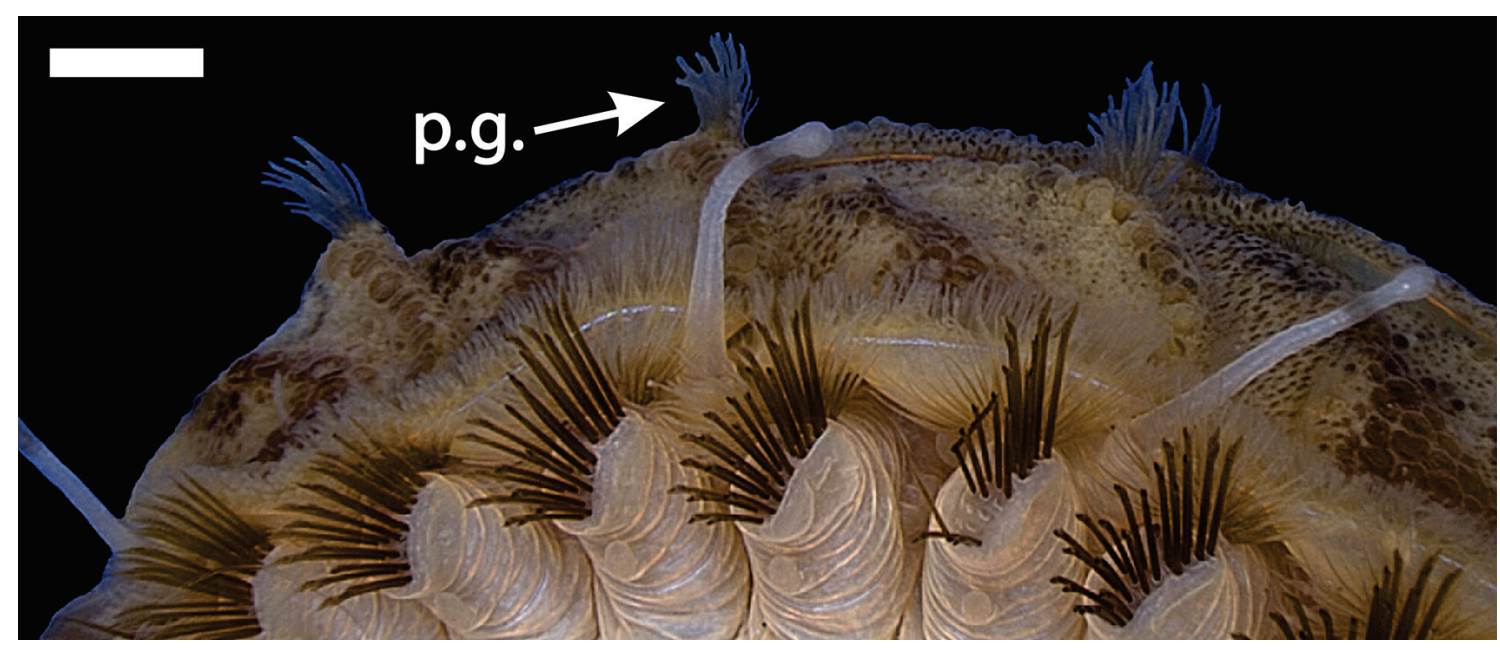

FIG. 5. Median chaetigerous segments of C. magnificus (lateral view), showing a group of papillae on border of elytrae (p.g. = papillae group). Scale bar: $(1 \mathrm{~mm})$.

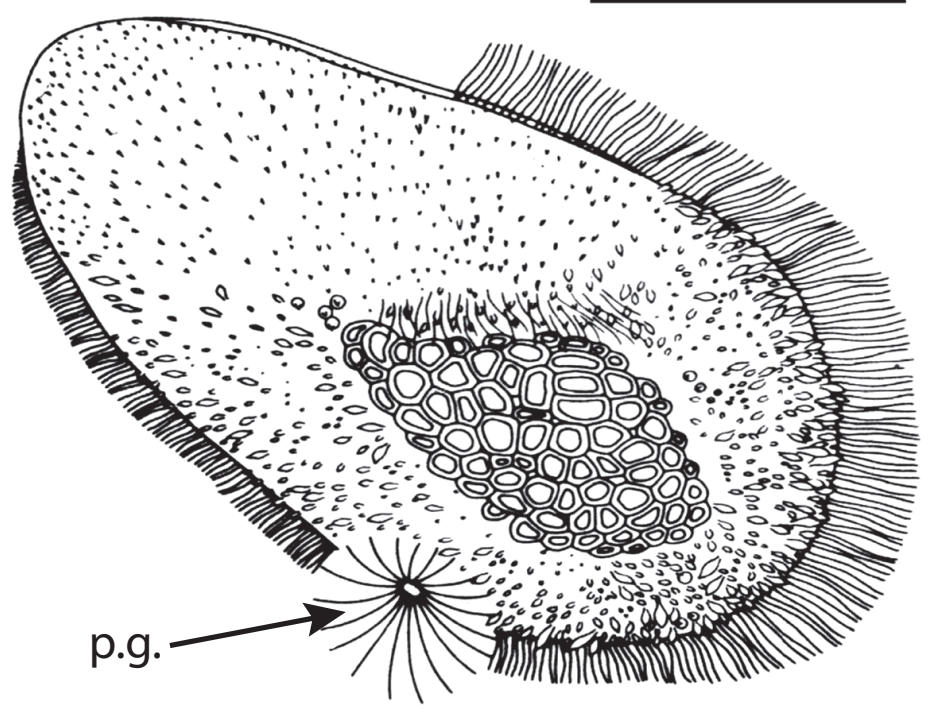

FIG. 6. Right elytra, group of papillae (p.g. = papillae group) modified from Amaral \& Nonato, 1982. Scale bar: (2mm). 


\section{REFERENCES}

Allen, M.J. (1957). The breeding of polychaetous annelids near Parguera, Puerto Rico. Biological Bulletin 13, 49-57.

Amaral, A.C.Z.; Nallin, S.A.H.; Steiner, T.M.; Forroni, T.O. \& Filho, D.G. (2012). Catálogo das espécies de Annelida Polychaeta do Brasil. Retrieved from http://www.ib.unicamp.br/museu_zoologia/files/lab_museu_zoologia/catalogo_polychaeta_amaral_et_al_2012.pdf.

Amaral, A.C.Z. \&Nonato, E.F. (1982). Anelídeos Poliquetos da costa brasileira: Aphroditidae e Polynoidae, vol. 3. Coordenação Editorial: Goiás, Brasília.

Augener, H. (1910). Bemerkungen über einige Polychaeten von Roscoff, über zwei neue Polynoiden des Berliner Museums, und über die Brutpflege von Hipponoe gaudichaudi Aud. \& M. Edw. Zoologischer Anzeiger 36, 232-249.

Fauchald, K. (1977). Polychaetes from intertidal areas in Panama, with a review of previous shallow-water records. Smithsonian Contributions to Zoology 221, 1-81.

Grube, A.E. (1876). Bemerkungen über die Familie der Aphroditeen. Gruppe Polynoina, Acoëta, Polylepidea. Jahres-Bericht der Schlesiche Gesellschaft fuer vaterlandische Cultur, Breslau 53, 46-72.

Hanley, J.R. \& Burke, M. (1991). Polychaeta Polynoidae: Scaleworms of the Chesterfield Island and Fairways Reefs, Coral Sea. In: Résultats des Campagnes MUSORSTOM, Vol. 8. Mémoires du Muséum National del Histoire Naturalle: Paris, France.

Hartman, O. (1938). The types of the polychaete worms of the families Polynoidae and Polyodontidae in the United States National Museum and the description of a new genus. Proceedings of the United States National Museum 86(3046), 107-134.

Hartman, O. (1939). Polychaetous annelids 1. Aphroditidae to Pisionidae. Allan Hancock Pacific Expedition 7, 1-155.

Hartman, O. (1948). The Polychaetous Annelids of Alaska. Pacific Science 2(1), 3-58.

Hernández-Alcántara, P.; Tovar-Hernández, M.A. \& Solís-Weiss, V. (2008). Polychaetes (Annelida: Polychaeta) described for the Mexican Pacific: an historical review and an updated checklist. Latin American journal of aquatic research 36(1), 37-61.

Imajima, M. (1997). Polychaetous Annelids from Sagami Bay and Sagami Sea collected by the Emperor Showa of Japan and deposited at the Showa Memorial Institute, National Science Museum, Tokyo: Families Polynoidae and Acoetidae. National Science Museum Monographs 13, 1-131.

Kinberg, J.G.H. (1856). Nya slägten och arter af Annelider, Öfversigt af Kongl. Vetenskaps-Akademiens Förhhandlingar Stockholm 12 (9-10), 381-388.

Laverde-Castillo, J.J.A. (1986). Lista anotada de los poliquetos (Annelida) registrados para el pacífico colombiano, con notas preliminares sobre su zoogeografía. Acta Biologica 15(58), 23-130.
Leach, W.E. (1816). Vermes Polychaeta. Encyclopedia Britanica 6, 451-452.

Monro C.C.A. (1928). Polychaeta of the families Polynoidae and Acoetidae from the vicinity of the Panama Canal, collected by Dr. C. Crossland and Dr. Th. Mortensen. Zoological Journal of the Linnean Society, London 36, 553-576.

Morgado, E.H. \& Amaral, A.C.Z. (1981). Anelídeos poliquetos associados a um briozoário. II. Palmyridae. Boletim do Instituto Oceanográfico de São Paulo 30(1), 87-89.

Nonato, E.F. (1981). Contribuição ao conhecimento de anelídeos poliquetas bentônicos da Plataforma Continental Brasileira, entre o Cabo Frio e o Arroio Chuí. Tese de Livre docência, Instituto Oceanográfico, Universidade de São Paulo: São Paulo, Brasil.

Nonato E.F. \& Luna, J.A.C. (1970). Sobre alguns poliquetas de escama do Nordeste do Brasil. Boletim do Instituto Oceanográfico de São Paulo18(1), 63-91.

Perkins, T.H. \& Savage, T. (1975). A bibliography and check list of polychaetous annelids of Florida, the Gulf of Mexico and the Caribbean region. Florida Marine Research Publications 14, 1-62.

Pettibone, M.H. (1983). A new scale-worm (Polychaeta: Polynoidae) from the hydrothermal rift-area off western Mexico. Proceedings of the Biological Society of Washington 96(3), 392-399.

Pettibone, M.H. (1984).Two new species of Lepidonotopodium (Polychaeta: Polynoidae: Lepidonotopodinae) from hydrothermal vents off the Galapagos and East Pacific Rise. Proceedings of the Biological Society of Washington 97(4), 849-863.

Pettibone, M.H. (1989). Polynoidae and Sigalionidae (Polychaeta) from the Guyamas Basin, with descriptions of two new species, and additional records from hydrothermal vents of the Galapagos Rift, $21 \mathrm{~N}$, and seep-sites in the Gulf of Mexico (Florida and Louisiana). Proceedings of the Biological Society of Washington 102(1), 154-68.

Rozbaczylo, N.; Moreno, R.A. \& Diaz-Diaz, O. (2005). Poliquetos bentónicos submareales de fondos blandos de la región de Aysén, Chile: Clado Phyllodocida (Annelida, Polychaeta). Investigaciones Marinas 33, 69-89.

Ruff, R.E. (1995). Family Polynoidae Malmgren, 1867. In: Taxonomic Atlas of the benthic Fauna of the Santa Maria Basin and Western Santa Barbara Channel. The Annelida Part 2. Santa Barbara Museum of Natural History: Santa Barbara, California, USA.

Salazar-Silva, P. (2006). Scaleworms (Polychaeta: Polynoidae) from the Mexican Pacific and some other Eastern Pacific sites. Investigaciones Marinas 34, 143-161.

Salazar-Vallejo, S.I. (1990). Poliquetos (Annelida: Polychaeta) de la Bahia de Manzanillo, con una clave ilustrada par alas especies de Colima, Mexico. Revista de Biologia Tropical 38, 211-229. 
Salazar-Vallejo, S.I. (1996). Lista de especies y bibliografía de poliquetos (Polychaeta) del gran Caribe. Anales del Instituto de Biología, Universidad Nacional Autónoma de México, Serie Zoología 67(1), 11-50.

Salazar-Vallejo, S.I. \& Londoño-Mesa, M.H. (2004). Lista de especies y bibliografía de poliquetos (Polychaeta) del Pacífico Oriental Tropical. Anales del Instituto de Biología, Universidad Nacional Autónoma de México, Serie Zoología 75, 9-97.

Seidler, H.J. (1922). Ueber die Untergattung Euphione. Zoologischer Anzeiger 54, 301-303.

Seidler, H.J. (1924). Beitrage zur Kenntnis der Polynoiden, I. Arch Naturgesch, Berlin 89 (11), 1-217.

Tebble, N. \& Chambers, S. (1982). Polychaetes from Scottish Waters, Part 1. Family Polynoidae. Roal Scottish Museum Studies, Edinburgh 1, 1-73.
Treadwell, A.L. (1901). The Polychaetous annelids of Porto Rico. Bulletin of the United States Fish Commission 20(2), 181-210.

Treadwell, A.L. (1914). Polychaetous Annelids of the Pacific coast in the collections of the Zoological Museum of the University of California. University of California Publications in Zoology 13, 175-234.

Treadwell, A.L. (1937). The Templeton Crocker Expedition, 8. Polychaetous annelids from the west coast of Baja California, the Gulf of California and Clarion Island. Zoologica $22,139-60$.

Willey, A. (1902). Polychaeta. In: Report on the collections of Natural History made in the Antarctic Regions during the Voyage of the Southern Cross. British Museum Natural History Publications: London, UK. 